\title{
Figures and maps
}

\section{Figures}

1 De Gaulle's words immortalised in stone on the front of Carlton Gardens. (Photo by Claire Atkin)

2 Carlton Gardens, the headquarters of the Free French. (Photo by Claire Atkin)

3 The Royal Victoria Patriotic Buildings, Wandsworth. (Photo by Charlotte Atkin)

4 The first edition of the Journal du Camp. (Photo by Reading University Library)

5 The statue of de Gaulle in Carlton Gardens. (Photo by Claire Atkin)

\section{Maps}

1 Principal ports visited by French refugee fishermen and their families in 1940. (Map drawn by Claire Atkin)

2 The sailors' camps in the North and Midlands. (Map drawn by Claire Atkin)

3 The principal Vichy consular offices in 1940. (Map drawn by Claire Atkin)

4 The London of the forgotten French: outer areas. (Map drawn by Claire Atkin)

5 The London of the forgotten French: inner areas. (Map drawn by Claire Atkin) 